\title{
Role and adverse effects of nanomaterials in food technology
}

\author{
Lahir Yogendra Kumar
}

Correspondence: lahiryk@gmail.com

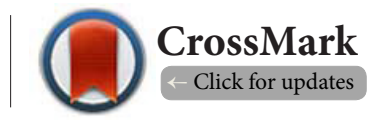

Department of Biophysics, University of Mumbai, Santacruz (E), Mumbai, India.

\begin{abstract}
Food processing is related to the practice adopted by the food and beverages industries to change raw plant and animal materials in to 'ready to eat form'. Nanomaterials are applied to food technology with respect to their properties and predetermined set goals such as taste, flavor, shelf-life, appearance, likes and dislikes of the consumers. Nanomaterials have specific potentials depending on their physicochemical properties such as surface effect, small size effect, quantum size effect and quantum tunneling effect. These properties regulate their behavior in the biosystem for they may be either tolerated or be the cause of disturbance to biochemical and/or physiological homeostasis. Mostly nanomaterials have the ability to reach target tissues or organs where their counterparts fail to reach in the organism. Nanoparticles like zinc, calcium and silver are found to be biocompatible and antimicrobial in nature. Hence, these are used in the form of edible film incorporated with cinnamon or oregano oil in the packaging of food. Generally, polymers are incorporated with the nanomaterials and are used in food packaging and food processing. Food processing is aimed at good food quality and safe evaluation by improving food sensing and better nanostructured ingredients. These nanomaterials improve the flexibility and durability of the food contents. The nanomaterials enter the body along with the food products, beverages and other drinks for consumption. Understanding the mechanism involved in toxicity due to nanomaterials may provide necessary information about the nanomaterials which will act as guide lines for their appropriate use in food technology and its related aspects. This will also help to develop more innovative devises to meet the future challenges in food technology. This overview is intended to evaluate the extent of overall role of nanomaterials in food technology.
\end{abstract}

Keywords: Nanomaterials, biocompatibility, food-packaging, food safety, food processing

\section{Introduction}

The food industry is one of the prime industries and a major target of application of nanomaterials. Food processing refers to the practice adopted by the food and beverages industries to convert the raw plant and animal materials in to ready to serve or eat form of food for consumers [1]. Media has played its significant role to build a strong public opinion in favor of the processed food products. As a result of this impact on public, the market has been infiltrated with huge number and varieties of processed food products [2]. Nanomaterials play an effective role in food preservation, packaging process and packaging material [3]. Candies, sweets, and chewing gums have gained popularity because of the use of nanomaterials [4]. This success is based on the sensitivity and efficiency of the products of nanoscience. Uses of nano-scale materials in the food industry are likely to improve the processed food [5]. Nanomaterials are being used as coated materials in treatment and as diagnostic tools [6].

Nanomaterials have unique properties such as surface effect, small size effect, quantum size effect and quantum tunneling effect. These have the ability to exist in aerosol, suspension, make them worthy of application in enhancing the utility of the food products. The surface and interfacial properties of nanomaterials can be modified with surfactants; these engineered nanomaterials exhibit flexibility. This facilitate in fabricating nanomaterials for various uses. Various types of nano-objects are involved in the formulation of nanomaterials such as nanoparticles, nanorods, nanotubes, nanocomposites, and nanofilm etc. These are used as per the need of applications in varied industries. Mostly nanopowder may include $\mathrm{TiO}_{2^{\prime}} \mathrm{SiO}_{2^{\prime}} \mathrm{ZnO}$,

(C) 2015 Lahir Yogendra Kumar; licensee Herbert Publications Ltd. This is an Open Access article distributed under the terms of Creative Commons Attribution License (http://creativecommons.org/licenses/by/3.0). This permits unrestricted use, distribution, and reproduction in any medium, provided the original work is properly cited. 
$\mathrm{CeO}_{2}$; colloidal dispersions and nano-suspensions involve gold, silver, silica etc. Food nano-sensing is related with food quality and safe evaluation while nanostructured ingredients help to improve food processing [7]. In a broadly sense, the nano-food processing is accomplished in three major aspects namely production (this pertains to over all conversion of raw food materials in to edible form), processing (it is related to modify the processed food with respect to taste, shelf life, protection against possible pathogens etc, as per the need of consumers) and to retain required nutritional values [8]. Agriculture and agrobased industries are the sources of raw materials for food industries. The involvement of nanomaterials in agriculture, food and food technology appears to be inevitable to meet the current demand of human population.

\section{Review}

\section{Applications of nanomaterials in food processing}

Food cycle includes all phases of food industry which are exploited in bringing food from field to table. It includes agropractice, post harvest practice and processing of raw food in to ready to eat-form. Agro-practice aspect is out of the current discussion but can be envisaged that use of pesticides, fertilizers on crops etc., are likely to be facilitated by some of the nanodevices. Post harvest aspect includes storing, aggregating the agriculture produce while processing of raw food deals with procuring grains, vegetables, fruits, and other ingredients in to processed food or ready to eat-form. Food nanotechnology goes a few steps ahead in making food palatable and its pleasant aftereffects by using nanomaterials in different forms at various stages of food processing.

Broad outline of the various stages of processing of food are packaging, designing and formulation, keeping the food fresh and usable form during storage, transportation, supply and disposal of the unused products beyond expiry period or spoiled food. The role of nanotechnology in these phases of the food industry has been established; it is becoming prominent, demanding and enduring day by day. Food processing implies that raw food is transformed in to pleasing, palatable, digestive, nutritive and hygienic form that can be consumed by humans. Elementarily, food processing remains relatively same though food and feeding habits are different in different parts of the world. The food processing has undergone varied changes in due course of time in accordance to the needs of the individual, life style and society. Application of the nanomaterials in food and food technology is based on the behavior of the nanoparticles; this behavior is primarily dependent on the scientific evidences obtained during the primary research. Ag and $\mathrm{ZnO}$ NPs play an effective role in maintaining the shelf-life of fresh orange juice and have recommended these NPs as safe material for food technology [9]. The major applications of nanotechnology in food engineering are as food nanosensing and nanostructured ingredients. Nanosensing pertains to better food quality and safety evaluation while nanostructured ingredients help to improve food processing. Improved food processing includes appropriate delivery of nutrients, bio-separation of proteins, fast sampling of biological, chemical contaminants and nanoencapsulation of nutraceuticals, stabilization, delivery and coloration of the food system [7]. Nanomaterials play an effective role to attain better encapsulation and release efficiency of active components of food in comparison to the traditional encapsulating agents. Some of the important food supplements are to be retained during the food processing and it is accomplished by using nanomaterials. Nanosized powders are used to elevate the degree of absorption of nutrients, nanoencapsulation of nutraceuticals which are used to increase absorption, better stability and targeted delivery, cellulose nanocrystal composites as drug carrier, vitamin spray dispersing active molecules as nanodroplets for efficient absorption and nanocochelates as coiled nanoparticles, are employed to ensure nutrients delivery to the cells without disturbing the color and taste of the food. Other varied modifications of nanomaterials include development of nanoemulsions, liposomes, micelles, bipolar complexes and cubosomes are effective in protection of bioactive ingredients, controlled delivery system, food matrix integration and masking the flavors that are undesirable [10]. Such manipulated enzymes are administered to enhance the bioavailability of essential nutrients that include essential minerals and vitamins and hydrolyze antinutrients. This practice of adding formulated enzymes ensures appropriate enzyme-substrate support system because this brings about higher surface to volume ratio as compared to traditional support system.

ZnO NPs are used in many nanostructures and have the ability to be fabricated in a wide range of morphological varieties [11]. Gelatinization of starch plays key role in processing of food based on starch because it influences the nutritional benefits (if starch used gets contaminated it can be the source of adverse effect) [12]. During the process of filtering beer from mother solution and procuring cheese from milk, nanoseives or nanomembranes are most commonly used [12]. Nanoparticles like zinc, calcium and silver are found to be antimicrobial in nature; hence, these are used in the form of edible film incorporated with cinnamon or oregano oil in the packaging of food. Nanofibers are fabricated from the shell of lobster and organic corn which are antimicrobial and can be easily biodegraded, thus, becomes preferred material for food processing. Prime concern of using nanomaterial is that the nano-additives should not carry insoluble biopersistant matter in the circulation of the consumer. Quite often food is spoiled because of oxidation of the organic and/or added components. A fabricated electrochemical biosensor (a redox biosensor) is able to detect phenolic compounds in the food within range $37 \mathrm{nM}$ to $4.33 \mu \mathrm{M}$ [13]. Nanoencapsulates, silver and $\mathrm{TiO}_{2}$ are among those nanomaterials that have been applied to the maximum extent [14]. Nanocomposites in the form of novel food, food or feed additives, biocides, pesticides and food contact materials have bright future in the field of food processing. 
During food processing nanotechnology assures many benefits such as safety, security, quality and shelf life of the food products [15]. This interaction between nanomaterials and processed food can cause unknown and unexpected hazard to the consumer. Nanomaterials are used as nanocapsules to enhance bioavailability of nutraceuticals, standard ingredients like cooking oil, to encapsulate flavor enhancers, to infuse plant based steroids to replace cholesterol of meat; nanoemulsions and nanoparticles are employed to increase availability and dispersion of nutrients. Nanotubes and nanoparticles are used as gelation and viscosifying agents while nanoparticles are involved in selective binding and removal of chemicals and pathogens from food under consideration. The potential application of nanomaterial science is being carried out with reference to nanoscaled biomaterial, packaging, sensors to increase shelf life, to detect development of undesirable factors [16]. Inorganic nanomaterials are used in healthy food products [17]. Transition metals and metals like Ag, Fe, $\mathrm{TiO}_{2}$, alkaline earth metals such as calcium, magnesium, and non-metals like silicates and selenium are extensively used in food processing. When children, at health center were fed ultra processed food, children aged 2-10 years, elder children (5-10 years) were found to consume relatively more ultra processed food in comparison to younger ones [18]. Silver zeolite is used as coated ceramic form; silver produced ROS which are responsible for the antimicrobial action [19]. Nanoiron is a suitable health supplement because it breaks down the contaminants and destroys microbes. Modified magnetic nanoparticles $\left(\mathrm{Fe}_{3} \mathrm{O}_{4}-\mathrm{SiO}_{2}-\mathrm{NH}_{2}\right)$ has been found to be relatively better agents for eliminating microbes and virus from water [20]. Further, nanomicelle based formulation involving natural glycerin is a very suitable option to remove pesticides residue from fruits and vegetables up to $99.9 \%$.

\section{Nanomaterials used in food packaging}

In general nanomaterials used in food packaging include nanofilms as barrier materials to prevent spoilage and oxygen absorption, electrochemical nanosensors to detect ethylene, antibodies linked with fluorescent nanoparticles to detect chemical and food borne pathogens. Common packaging for processed food, beverages and other related products in which nanomaterials are exploited sandwich bags; salad bowl, carry bags, bear bottles, aluminum foils, etc. The polymers incorporated in the nanomaterials improve the flexibility and durability of the food contents. The engineered nanomaterials (ENMs) used nullify the effects of temperature, humidity and act as barriers for the potential organisms to harm or spoil the food thereby enhancing the stability of food. The ENMs incorporated with plastic polymers have antimicrobial properties that are used to monitor the condition of packed food. The fabricated packaging materials with such specific qualities are termed as improved nanocomposite/active nanocomposite and smart packaging [12]. When such types of engineered nanomaterials are used for food packaging there are chances of migration of the nanomaterial towards food, drinks, or any edible matter packed therein, this migration is prevented to a greater extent. The bottles or the containers to be used for packing drinks, beverages, and other edible material contains nanoclay composite; these composites are embedded in the layers of polyethylene terephthalate (PET). There are no detectable movements of nanoclay from PET to the food contents or drinks packed. Those engineered nanomaterials that have smaller size than $1 \mathrm{~nm}$ could migrate through packaging because polymer matrices materials exhibit relatively lower dynamic viscosity and no interaction between the two [21]. When nanocomposite specifically involving silver and polyolefines were used for packaging then there seemed to be some chances of migration of very small nanomaterials but not the bigger ones. The bigger nanomaterials get bound to the polymer matrices such as polystyrene and polyethylene terephthalate because of the relatively higher dynamic viscosity. Very low degree of migration of Ag NPs occurred from containers made of polypropylene nanosilver-composite. There was no transfer of non-nanocomposite material from the intelligent, smart and active packaging fabricated nanotechnologically like inks, reactive nanolayers and analyte at nano scale. These packaging materials provide non-toxicity, safety standards as per the legislations, reliability of products and after- use disposal issues are taken care [12]. Research and development both are aimed to maintain specific safety standards keeping the expectations of consumers and to maintain the environment. The label on the packages are improvised with radiofrequency identification display (RFID), this technique is able to track the food product during its transportation and distribution. Antimicrobial activity of $\mathrm{ZnO}$ powder coated PVC film with respect to food pathogens revealed that electrostatic interaction between bacterial cell surface and nanoparticles inhibited the growth of pathogens [22]. Nanomaterials like CNT, silicon nanowires, $\mathrm{ZnO}$-nanorods etc, elevated the detection capability of biomolecules [23]. Those nanomaterials that have small dimensions and unique physical, chemical and optical properties ensure the safety of food and other contents of processed products along with the detection of spoilage in packed conditions. Hence, these are most suitable and ideal as bioprobes and biosensors [13]. Nanomaterial such as cubosomes $(5-10 \mathrm{~nm})$, liposome $(20 \mathrm{~nm})$, micelles $(5-500 \mathrm{~nm})$ have the ability to encapsulate biopolymeric nanoparticles like starch, chitosan, polylactic acid, gum Arabic, carrageenan, and alginate etc, and fabricated to be used in smart packaging material [23]. The new generations of such nanoencapsulation system are double layered liposomes, solid-lipid-nanoparticles, colloidosomes, nanolaminates and composite nanofibers, incorporated while plastic polymers are combined with nanoclay to fabricate stronger and cleaner, flame resistant material with a higher degree of reliability. These materials meet the requirements of the manufacturer, consumers of the food and food technology.

Bayer Polymers have fabricated a film involving silicate 
nanoparticles. It prevents the movements of oxygen and other gaseous material and transfer of heat, retaining the moisture contents of food packed [12]. In the recent past nanoparticles like silver, $\mathrm{ZnO}, \mathrm{MgO}$ are being used in beer packaging to prevent contamination of food and beverages because of their antimicrobial nature. Polylactic acid when incorporated with small concentration of silica nanoparticle becomes biodegradable material, cost effective, available commercially, and acted asa suitable packaging material [24]. If the resultant polymer matrix were incorporated with nanofillers its physicochemical properties were enhanced due to small size and increased area, its efficiency was observed to be increased many folds. Nanowheels are the devices which are bimetallic and in the form of 2D nanostructure. These are good materials to maintain heat and catalytic reactions of the food contents in packaging because these exhibit well-defined tunable surface resonance [25]. Food and crops are most vulnerable to microbial and fungal infection at any stage of food technological cycle and there is a dire need to protection where nanomaterials can be very useful $[26,27]$. Studied on antimicrobial activity of ZnO NPs with respect to E. coli and Pseudomonas aeruginosa and antifungal activity against Aspergillus niger, revealed that maximum inhibition was found to be at $100 \mu \mathrm{l}$, with concentration of ZnO NPs in $100 \mu \mathrm{l}$ was $100 \mu \mathrm{g}$ and $400 \mu \mathrm{l}$ respectively; because of the specific antimicrobial nature of ZnO NPs against food borne pathogens hence, these are used in food packaging and food preservation [28]. Nanoscaled electrospun fibers and encapsulated active compounds very effective in increasing the shelf life of the packed food [16]. Eugenol (a phenylpropene, an alkyl chain substituted guaiacol compound clear to pale yellow in appearance), it is a stable and preferred and successful preservative. Eugenol has antibacterial and antifungal properties. This compound is advantageous as it has the ability to regulate the release of the active encapsulated contents and is advantageous for effective pay-loads [29]. Nanocellulose (microfibrilated cellulose)-another biomaterial, used for packaging of food is preferred and other applications because the fabrication is relatively much easier than production of CNT [16]. Nanotechnology is involved in developing nanomaterials which have a specific degree of permeability, nanomaterials with enhanced barrier characteristics and mechanical features, antimicrobial and anti fungal surfaces and higher degree of biodegradability $[19,30]$. These new generations of nanomaterials are expected to meet most of the requirements of the future.

\section{Fate of nanomaterials used in food-distribution and elimination}

The nanomaterials enter the body of consumer along with food, beverages and other drinks. The ingested nanomaterials along with food undergo physiological changes. Some of these are likely get absorbed either directly or with absorbed food components. Size, shape and structure predispose them to cross the biological barrier of the gastrointestinal tract. These nanomaterials remain in the system either in bounded or unbounded form at least for some duration. During this period these interact with biomolecules either beneficially or adversely. Their elimination from the body is brought about by different modes depending on their interaction with biomolecules and physicochemical features. Specifically the engineered nanomaterial designed for specific purpose may pose a problem during their elimination from the body depending on the type of fabrication and material used.

The investigation related to elimination of quantum dots in vivo indicated that the behavior of QDs depended on the size, and surface chemistry. Those QDs which had coating of cysteine and $5.5 \mathrm{~nm}$ diameter were eliminated through kidney while QDs with different dimension and surface properties need further investigation [31-33]. Opsonization (a process that prepares foreign materials or marks the pathogen for phagocytosis) occurs depending on their size and surface features during the process of elimination of nanomaterials [34]. Orally administered nanomaterials get absorbed and move across gastrointestinal tract and distributed in the body parts like kidney, liver, spleen, brain and respective target organs. Most of the orally administered nanomaterials were eliminated along with the feces and/or urine [35]. Higher concentrations of nanomaterials were excreted via kidney, hepatobiliary pathway. When neural and neuronal cell lines were exposed to carbon nanotubes, these grew and were better differentiated $[36,37]$. The nanomaterials were found to be cleared by macrophages by phagocytosis; the phagocytosis was enhanced by chemotactic attraction at least in the alveolar zone $[35,38]$. Clearance of nanomaterials occurred as soon as these materials reach various organs of the body or circulatory system; clearance process was accomplished by live and phagocytotic process of macrophages in spleen and other organs [39]. When nanomaterials like polysorbate (used in food and pharmaceuticals) 80-coated PBCA and pegylated PLA immunonanoparticles, were administered intravenously, could move through blood brain barrier and were found to be accumulated in the brain tissue resulting in neurotoxicity due to the respective physicochemical features [40]. ZnO nanoparticles (50 $\mu \mathrm{g} / \mathrm{g}$ wt of egg, $50 \mu \mathrm{g} / \mathrm{g}$ wt of egg) reach in the embryonic hepatic tissue within 24 to $48 \mathrm{hr}$ when administered in chorio-allantoic fluid in the egg (chicken) on 18/19 day during the incubation [41]. The human red blood cells exhibited viability and hemolytic response against $\mathrm{ZnO}$ nanoparticles ( $20 \mu \mathrm{g} / \mathrm{ml}, 30 \mu \mathrm{g} / \mathrm{ml}$ and $40 \mu \mathrm{g} / \mathrm{ml}$ ) [42]. ZnO nanoparticles, $20 \mathrm{~nm}$ and $70 \mathrm{~nm}$ sized $\mathrm{ZnO}$ NPs were administered orally in male and female rats. The concentration in plasma, liver, lung, and kidneys was found to be increased within 24 hr after administration following dose-dependent pattern. Degree of renal elimination of these nanoparticles was very less as compared to fecal elimination. ZnO NPs were unevenly absorbed in to blood circulation form gastrointestinal tract [43]. The excretion of $\mathrm{TiO}_{2}$ and $\mathrm{ZnO}$ nanoparticles in Spargue- 
Dawley rats using dose $(1041.5 \mathrm{mg} / \mathrm{Kg}$ body weight, for 13 days). The tissues considered for excretion were blood, liver, kidney, spleen, brain, and urine and feces. $\mathrm{TiO}_{2}$ was observed to be less in these tissues in comparison to $\mathrm{ZnO}$ nanoparticles. $\mathrm{ZnO}$ NPs were observed to be very low in brain and spleen as

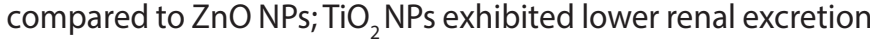
was in comparison to ZnO NPs while ZnO NPs were excreted in greater amount via urine but in feces it was very low in comparison to $\mathrm{TiO}_{2} \mathrm{NPs}$ [44]. Intestinal goblet cell secretion path way is one of the modes to eliminate the nanoparticles from the biosystem. This was investigated by injecting 30-200 $\mathrm{nm}$ sized activated carbon nanoparticles in the yolk of Zebra fish, these nanoparticles were excreted directly in the lumen if intestine and hepatobiliary path was not preferred [45].

Most of the nanomaterials present in circulation in the body are cleared by reticuloendothelial cells. Those nanomaterials which degrade slowly and show a low degree of renal clearance get accumulated in liver and spleen. Nanomaterials having size around $5 \mathrm{~nm}$ and present in blood circulation undergo renal clearance. Those having 10-20 nm are separated by liver; $200 \mathrm{~nm}$ sized NPs get picked up by Kupffer's cells and sinusoidal spleen. Others are taken care of by macrophages, opsonin assisted NMs undergo phagocytosis [46]. All of these varied observations related to various nanomaterials prove that most of these get distributed in biosystem and also follow a specific path for their elimination irrespective of the selected and intended purposes.

\section{Evaluation of nanomaterials before theiruse in food technology}

There have been tremendous applications of nanomaterials in the occupational, environmental and consumer sectors. This has elevated the public concern with respect to adverse effects and health hazards. This concern is expressed as risk factor in consumers. Intense use of engineered nanomaterials in almost every aspects of human life has raised the concern in the minds of the consumers. The nanomaterials at the work place are effective and likely to cause adverse effects (poor working conditions or because of the negligence) either immediately or at a later stage of life. Worker may suffer from the derogative effects of these nanomaterials (either acute or chronic toxicity) depending on his/her general health. The worker may experience this impact either during the tenure of the job or latter part of the life.

The toxicity of pristine and functionalized carbon nanotubes were observed from mild to moderate levels of toxicity; there are many issues that demand for research approach complementary to in vivo investigation related to understanding the biochemical, physiological aspects and health hazard related to nanomaterials [47]. There are specific techniques to engineer safe nanomaterials for the varied uses [48]. There is a need to understand the risk and beneficial aspects of the nanomaterial to be used. This whole approach should be nanorelevant. During the analysis one should consider the effect of nanomaterials with respect to heterogeneity, morphology, complexes formed (after nanomaterial is mixed with food). Thus, there should be clear protocol related to collection of the sample, strategies concerned with consumed food, type of processed food, amount of food consumed and the movement of food in the alimentary canal from where food sample is to be procured for analysis [49]. These precautions will ensure the safety from the nanomaterials while being exploited in the field of food technology and related agrobased industries. The evaluation of safe use of nanomaterials is of great significance to ensure most of the beneficial effects rather than adverse. Nanomaterials like $\mathrm{ZnO}, \mathrm{Ag}, \mathrm{Au}, \mathrm{TiO}_{2^{\prime}}$ quantum dots, dendrimers, nano-prosthetic, nanocomposite etc, if judicially exploited will result in beneficial impact. Ampelopsin is a major flavonoid, a potential antioxidant that prevents rancidity in diets; hence, can be used in food products [50].

\section{Tolerernce of nanomaterials used in food technology} Nanomaterials to be used in food technology should be tolerant to the consumer and if these result in adverse impact their use in food products is futile. Biocompatibility of nanoparticles is their ability to coexist within the body of a biosystem without disturbing the biochemical or molecular integrity of cell or tissue. Biocompatibility is regarded as the 'ability to be in contact with living system without causing adverse effects or biohazards are safely manipulated, $[\mathbf{5 1}, \mathbf{5 2}]$. Compatibility has been redefined as the ability of a chemical to carry on its designed function with respect to a biochemical/medical therapy without causing any local or systemic adverse effect in the body of the recipient and have potential to create beneficial cellular and/or tissue response in the given conditions with optimum performance [53]. Biosystems include microbes, wild varieties and domestic organisms; domestic organisms encompass agriculture crops, poultry, animal husbandry, organisms of aesthetic value and others used for scientific research. This ability of coexistence depends on the interaction between the specific nanomaterial and the specific species; this interaction is likely to be varied depending on the specie specificity. Biocompatibility may show fluctuations, beneficial and derogative state; these associations are related to nurturing the survival of a biosystem in given environmental conditions.

The compatibility of nanomaterial depends on the dose, type, size, physicochemical nature, type of the tissues, number and the duration of exposure and the photoperiod. Regulated lower doses of nanomaterials are preferable for survival and to evaluate their biocompatibility in a biosystem. It is appropriate to avoid those interactions which disturb the biocompatibility such as surface oxidation, photosensitivity etc, to ensure appropriate tolerance. The biocompatibility can be ensured or enhanced by taking preventive steps such as coating the suspected surface, evaluating photo-effect (incase photosensitive nanomaterials) etc, of the nanomaterials under consideration. Zinc is one of the inorganic elements 
which are needed by human body; zinc oxide is non-toxic to man but it is toxic to microorganisms. $\mathrm{ZnO}$ nanoparticles are biocompatible to man, hence, can be suitable in the role of biosensors [54]. Biocompatibility of nanomaterials can be enhanced by self assembly with chitosan and modified lecithin [55]. Biocompatible gold nanoparticles can be formulated with green chemistry approach [56]. Inorganic nanoplate for of nanomaterials can be used as theranostics for cancer [46].

\section{Biological adverse effects due to nanomaterials used in food}

Nanomaterials are used in abundance in food technology. The processed food products have been infused with nanomaterials. These carry nanomaterials in the gastrointestinal tract of the consumers. These in turn undergo physiological changes. As a result there is every possibility that these nanomaterials are likely to interact with the tissue, cellular organelles, and biomolecules. This interaction may be beneficial and/or adverse physiologically, biochemically, cytologically, histologically or genetically. Some of the nanomaterials like metallic and metallic-oxides nanoparticles, quantum dots, fullerenes, and fibrous nanomaterials have been found to cause adverse effects that include fragmentation of chromosome, breakage of strands of DNA, changes in gene precision etc. There are reports on clinical toxicity but major studies indicate that nanomaterials are able to initiate adverse biological interactions leading to untimely physiological disruption and toxicological out come in due course of time.

Silica nanoparticles cause oxidative stress and resulted in cytotoxicity in vitro and in vivo; elevated lipid peroxidation, LPO, ROS, and declined level of cellular glutathione $[57,58]$. There is every possibility of known and unknown varied hazards based on systemic investigation on cells treated with nanomaterials with respect cytotoxicity and inflammation [59]. AuNPs and Ag NPs have potential to caused depolarization of a-tubulin-major component of microtubule, affecting adversely the cellular structure and associated cytoskeleton of the cell [60]. The mechanism involved in the interaction between nanomaterials and living biosystems is still ambiguous [61]. The efficacy of nanomaterials with which these interact with biological molecules in the ambient atmosphere and the formation of varied end products is highly complex phenomenon. This complexity becomes more challenging with the slight changes brought about in the nanomaterials due to coating, charge, size, surface properties, dispersion, agglomeration, concentration and matrix.

Nanomaterials have the potential to cause mutagenicity, clastogenicity, aneugenicity (causing the possession of abnormal chromosome numbers), apoptosis, autophagy and mitoptosis (death of mitochondria) etc, [6]. There is lot of toxicological data related to cytotoxicity, genotoxicity, repeated dose toxicity and biokinetics are available related to silica, titanium dioxide, and silver; there are limited records concerned with the use of nanomaterials in agriculture, food, feed application [14]. The resume of legislation and regulations in European and non-European countries have adopted EU legal acts and formulated the guide lines to be followed for the related industries.

Mostly iron oxide nanoparticles enter mammalian cells via endocytosis, sometimes by pinocytosis, through reticuloendothelial system, while in blood circulation opsonization of nanoparticles to cell surface was also involved. Internalization of iron oxide nanoparticles was observed to be directly related to their size [62]. Graphene induced toxicity and apoptosis in cell culture has been observed; this adverse response was found to be in relation to dose and duration dependent. Graphene (100-110nm) also caused cytotoxic state and damage to mitochondria in case of neural cells also [63]. Carbon nanotubes cause varied toxic response depending on the type and the applications [64]. The toxicity of dendrimers depended on their size and shape as these nanomaterials exhibit closeness/resemblance to the components of the cells like DNA, proteins etc. Their structural aspects were found to be very suitable to provide space for encapsulation of food ingredients and therapeutic drugs, imaging molecules and conveniently regulated the release. This specific feature was also able to reduce toxicity. However, these nanomaterials exhibit hemolytic and hematological toxic responses in a given biological system. Their features such as cationic surface charge and the negative charge on the biological membrane interact leading to the toxicity in vivo [65-67]. To counteract this adverse effect these are engineered to be biocompatible and biodegradable. During the experimentation with quantum dots, the observation indicated oxidative stress; influencing signaling pathway between macrophages. The interaction of QDs was found to be dose dependent and exhibited adverse effects on cell division and the growth of the cell [68]. Engineered nanoparticles relevant to various industries like $\mathrm{SiO}_{2}$, $\mathrm{ZnO}, \mathrm{Fe}_{2} \mathrm{O}_{3^{\prime}} \mathrm{Ag}, \mathrm{CeO}_{2^{\prime}}$, had exhibited dose dependent elevated cytotoxicity and damage of DNA, affected cell proliferation in human lymphoblastoid and adherent ovary cell culture [69].

The metal oxide NPs, metallic NPs, quantum dots, $\mathrm{SiO}_{2} \mathrm{NPs}_{\text {, }}$ CNT and other nanomaterials with respect to size, shape, surface charge, type of coating material, reactivity, dose, exposure, route of administration exhibit toxic behavior. Further, it was found that stable metallic oxides, mostly have not shown toxicity but metallic NPs bring a change in reduction potential which causes cytotoxicity and genotoxicity. Those NPs which were in soluble form were definitely found to be toxic in comparison to non-soluble [70]. C60 got linked with the DNA at its minor grooves and initiated unwinding; when it got linked with RNA it inhibited replication of DNA [71]. When $\mathrm{C} 60$ bound to nucleic acid the range of energy involved varies within -56 to $-10 \mathrm{kcl}^{\mathrm{mol}}{ }^{-1}$ depending on the different genomic fragment [71]. There are views with respect to optimization of immobilized enzymes, immunodiffusional limitations, maximum surface area per unit mass and high effective enzyme loading. Further, nanoparticles affect the behavior of the 
enzymes in transitional region/phase between heterogeneous (immobilized) enzymes and homogeneous (with soluble free enzyme) enzyme catalysis. These nanoparticles influenced the reaction particle mobility related to the particle size and solution viscosity [72]. Polystyrene particle when used on an enzyme model a-chymotrypsin it got attached to NPs covalently up to $6.6 \mathrm{wt} \%$. Factors such as change in particle size, viscosity of the reaction medium affect the mobility of the enzyme catalyst; there is a change in the intrinsic activity of the said enzyme (the particle attached enzyme), Km, Kcat were found to be affected because of the particle size and viscosity [72]. Structure and function of an enzyme can be changed by nanoparticles; the enzyme-nanomaterial interaction is governed by the key properties such as structure, size, shape, surface chemistry and charge. This is because of the electrostatic complementarities between carboxylate end group and cationic residues present around the periphery of the active site [73].

When the surface of the nanoparticles was modified, these NPs affected the enzyme function in comparison to traditional materials. This factor could be modified with organic molecules via covalent or non-covalent modification to prepare functional nanoparticles. Suitably functionalized nanoparticles posses some specific abilities like preventing non-specific binding and recognizing specific biomacromolecules; this aspect of modified nanomaterials could specifically regulate enzyme activities [48]. The effects of iron oxide NPs on tissue and the enzymes of live in rats, caused hepatotrophic effects; the levels of alkaline phosphatase, aspartate amino transferase and alanine amino transferase enzyme activities were elevated [73]. Single enzyme NP of celluloclast B G, cellulose enzyme (SEN-CK) has the ability to degrade great substrate like cellulose and the stability of the SEN-CK enzyme has been found to be significantly better than that native enzyme [74].

Moderate doses of gold, silver and ZnO NPs (50 ppm, average size of NP10nm; 25, 50 100ppm) elevated LDH activity with all concentrations of the three nanoparticles used [75]. Specific and unique features of nanomaterials are the factors that affected toxicity and their interference during the assessment processes. Nature of nanomaterials and the mode of the behavior of the respective nanomaterials in the biosystems remain ambiguous in the current scenario of the toxicity assessment pattern [76]. One of the physiological and biochemical disturbances caused is related to change in the redox potential in the affected cell/tissue; reactive species of oxygen and nitrogen caused lipid oxidation and this condition can be created by nanomaterials [77]. SPION showed uniform distribution endothelial cells; this distribution was affected by the parameters like shape, size and other geometrical aspects and conditions related to hemodynamics [78]. Nature, type of coating on quantum dots the major parameters that played an effective role in their toxic activity; features like size, charge and the surface coating are the deciding factor of their uptake, mechanism of internalization and toxic behavior Table 1 [79].

Table 1. Some of the adverse responses of nanomaterials.

\begin{tabular}{|c|c|c|}
\hline Nanomaterials and parameters & Tissues/cells and Responses & References \\
\hline CNT (single walled C-nanotube; $24 \mathrm{mg} / \mathrm{ml}$ & $\begin{array}{l}\text { Plasma membrane destabilized, declined viability, oxidative stress induced } \\
\text { and caused change in ultra structural morphological changes }\end{array}$ & {$[80]$} \\
\hline Single walled C-nanotubes $200 \mu \mathrm{g} / \mathrm{ml}$ & $\begin{array}{l}\text { Inhibited cell proliferation, induced apoptosis, reduced the ability of cell } \\
\text { adhesion, viability loss of embryonic renal cells }\end{array}$ & {$[81]$} \\
\hline $\begin{array}{l}\text { Single walled C-nanotubes and multiwalled } \\
\text { nanotubes, } 22.6 \mu \mathrm{g} / \mathrm{ml}, 226 \mu \mathrm{g} / \mathrm{ml}\end{array}$ & $\begin{array}{l}\text { High toxicity in macrophages in alveolar tissue, loss of viability, } \\
\text { detachment of cells and change in protein expression }\end{array}$ & {$[82]$} \\
\hline Single walled nanotubes $24 \mathrm{hr}$ & $\begin{array}{l}\text { Morphological changes in lamellar structures, microvilli, tonofilaments and } \\
\text { desmosome junctions in relation to cell membrane }\end{array}$ & {$[83]$} \\
\hline $\mathrm{Al}_{2} \mathrm{O}_{3}, \mathrm{CeO}_{2}, \mathrm{TiO}_{2}$ metal oxides nanoparticles & $\begin{array}{l}\text { Change in membrane potential, induce lipid peroxidation and oxidative } \\
\text { stress, cytotoxicity was observed, }\end{array}$ & {$[84]$} \\
\hline $\begin{array}{l}\text { Cationic nanoscale materials (related to } \\
\text { surface charge) }\end{array}$ & $\begin{array}{l}\text { Spherical NPs were taken up } 500 \% \text { more readily than rod shaped NPs, } \\
\text { internalized NPs bombarded the endosomes and reached cytosol machin- } \\
\text { ery, cationic NPs move across the cell membrane by forming transient } \\
\text { opening and due to hydrophobicity, induced cytotoxicity }\end{array}$ & {$[85]$} \\
\hline Silica NPs & $\begin{array}{l}\text { Resulted cytotoxicity, caused oxidative stress in vivo and in vitro, elevated } \\
\text { lipid peroxidation resulting rise in ROS and decline in cellular glutathione } \\
\text { (GHS) }\end{array}$ & {$[58,86]$} \\
\hline $\begin{array}{l}\text { Gold NPs (AuNPs), Silver NPs (AgNPs), } \\
\text { CoCrNPs }\end{array}$ & $\begin{array}{l}\text { Depolarization of } \alpha \text {-tubulin, disturbing the cellular structure, partial } \\
\text { fragmentation of Protein }\end{array}$ & {$[60]$} \\
\hline Silver zeolite NMs & Produces reactive oxygen species & {$[19]$} \\
\hline Carbon nanotubes & Causes inflammation in neural cells (glial cells), cytokine & {$[87]$} \\
\hline Dextran coated SPION(20nmand $60 \mathrm{~nm})$ & Induced proinflammatory cytokine & {$[86]$} \\
\hline Colloidal gold NPs $(1 \mu \mathrm{M} / 5 \mu \mathrm{L})$ & Affected electrical activity in retina but no morphological changes & {$[87]$} \\
\hline
\end{tabular}


Lahir Yogendra Kumar, Journal of Toxicology and Health 2015,

http://www.hoajonline.com/journals/pdf/2056-3779-2-2.pdf

Continuation of Table 1.

\begin{tabular}{|c|c|c|}
\hline Nanomaterials and parameters & Tissues/cells and Responses & References \\
\hline ZnO NPs $(50 \mu \mathrm{g} / \mathrm{g}, 150 \mu \mathrm{g} / \mathrm{g})$ & Atrophy of embryonic hepatic tissue (chicken) & {$[41]$} \\
\hline ZnO NPs $(20 \mu \mathrm{g} / \mathrm{ml}, 30 \mu \mathrm{g} / \mathrm{ml})$ & Hemolysis of human red blood cells & {$[42]$} \\
\hline Copper NPs $413 \mathrm{mg} / \mathrm{K}^{-1} 5000 \mathrm{mg} / \mathrm{K}^{-1}$ & Pathological damage to liver, kidney, spleen & [39] \\
\hline CdSeQD with $\mathrm{ZnO}$ shell $0.014 \mu \mathrm{g} / \mathrm{kg} /$ day & $\begin{array}{l}\text { Increased gastric toxicity in presence of simulated gastric fluid, induce ac- } \\
\text { cumulation in body tissues }\end{array}$ & {$[88]$} \\
\hline Silver NPs $125 \mathrm{mg} / \mathrm{kg}, 60 \mathrm{~nm}$ & Elevated cholesterol and cholestric enzyme & {$[88]$} \\
\hline $\begin{array}{l}\text { Coated QD (bidentatethiolatedhydrocarbonic } \\
\text { acids, silica, lipid micelles) }\end{array}$ & Induced the release of proinflammatory cytokines leading to cytotoxicity & {$[79]$} \\
\hline $\begin{array}{l}\text { Gold, silver and ZnO NPs } 10 \mathrm{~nm} ; 25,50 \text { and } \\
\text { 100ppm }\end{array}$ & Caused increase in LDH activity & {$[75]$} \\
\hline $\mathrm{TiO}_{2}$ (in respiratory tract) & Caused oxidative damage to DNA and inflammation genetic instability, & {$[89]$} \\
\hline $\mathrm{TiO}_{2}$ (industrial grade) & $\begin{array}{l}\text { Higher degree of deletion of DNA, pups exhibit dose dependent DNA } \\
\text { strand breaks }\end{array}$ & {$[88]$} \\
\hline $\mathrm{SiO}_{2}, \mathrm{ZnO}, \mathrm{Fe}_{2} \mathrm{O}_{3}, \mathrm{Ag}, \mathrm{CeO}_{2}$ & Caused dose dependent DNA damage & {$[69]$} \\
\hline $\begin{array}{l}\text { SWNT, MWNT (less than } 2.5 \text { micron } \\
\text { Particulate Matter) }\end{array}$ & Damaged mtDNA, increased aortic plaque & {$[90]$} \\
\hline C60 Nanoparticle & Bind to DNA and RNA and damages them & {$[71]$} \\
\hline Polystyrene particles $(110 \mathrm{~nm}$ to $1000 \mathrm{~nm}$ & Affected the intrinsic activity of enzyme model $\alpha$-chymotrypsin, & {$[72]$} \\
\hline anionic MMPCs (protected nanoclusters) & Effectively inhibited the chymotrypsin activity. & {$[91]$} \\
\hline $\begin{array}{l}\text { Silicon nanowires ( } \mathrm{SiNW}-\mathrm{SiO}_{2} \text {-functionalized } \\
\text { with carboxyl group and highly reactive } \\
\text { hydrogen modified ( } \mathrm{SiNW}-\mathrm{H})\end{array}$ & $\begin{array}{l}\text { Inhibited the enzyme activity of restriction endonuclease and Taq DNA } \\
\text { polymerase. }\end{array}$ & {$[92]$} \\
\hline Iron oxide NPs & $\begin{array}{l}\text { Increased the levels of alkaline phosphatase, aspartate amino transferase } \\
\text { and alanine amino transferase enzyme activities }\end{array}$ & {$[93]$} \\
\hline $\begin{array}{l}\text { Iron oxide NPs, } 30-35 \mathrm{~nm} \text { diameter, } 7.5,15 \text {, } \\
30 \mathrm{mg} / \mathrm{kg}\end{array}$ & $\begin{array}{l}\text { Enzyme activity of GSH, SOD and CAT declined as the concentration of } \\
\text { NPs increased }\end{array}$ & {$[94]$} \\
\hline
\end{tabular}

\section{Conclusion}

Nanotechnology is a multi-interdisciplinary technology having multifaceted applications. Its products are exploited in the formulation of personal care, health care, commercial and industrial applications. This ability is in relation to the structure, function and functionalization of either some groups of a molecule or molecule as a whole. Nanomaterials are being exploited in the processing of raw food to 'readyto-eat state'. This journey of food involves conversion of raw food in to prepared food (preprocessing), processing, packaging, transporting, supply, storage and disposal of expired or spoiled food and the packaging material. Nanomaterials are applied to food technology with respect to their properties and predetermined set goals such as taste, flavor, shelf-life, appearance, likes and dislikes of the consumers and the financial and commercial aspects. Prior to use of the nanomaterial it is quite essential to evaluate their biocompatibility to establish their utility in food or the consumer's intention to attain and maintain good active health. Processing and packaging is an essential aspect; its efficiency and effectiveness depends on the material used to pack the food to keep it fresh, usable, retention of nutritional values for the varied age groups. Biosensors are the devices which help to detect any derogative changes, infection or degree of spoilage of food packed. It is quite important to know distribution, fate and elimination of the nanomaterial from the body of the consumer. Various forms of nanomaterials devised, fabricated such as nanoparticles, nanofibers, nanomembranes, nanotubes, liposomes, nanofilms, etc, are used in food and food technology. It is very essential to estimate the over or abuse of these materials to avoid adverse effects. Study related to nanotoxicity is an appropriate approach to find an optimum, beneficial doses of nanomaterials to be used and their elimination from the biosystem. Even though it is claimed that the amount used of these products is within safe limits but the amount released directly or indirectly in the environment is comparatively much higher. Perspective of use of nanomaterials lies in the hands of personals involved in the field of nanotechnology, food technology and those trying to understand the adverse effects. The insight of the mechanism involved in interaction of nanomaterials and biosystems will guide the appropriate and effective manipulation for the good of man-kind and environment.

\section{Competing interests}

The author declares that he has no competing interests. 


\section{Publication history}

Editor: Cengiz Gokbulut, Balikesir University, Turkey.

Received: 07-Aug-2015 Final Revised: 28-Sep-2015

Accepted: 10-Oct-2015 Published: 19-Oct-2015

\section{References}

1. Monterio $C R$ and Levy R B. A new classification of food based on extent and purpose of their Processing. Public Health Nutrition. 2011; 25:20392049.

2. Kathleen S, Christopher M, Lynn L B, Marilyn H, Chen J, Henry K and Jane $H$. Nanotechnology and the environment. C R S Press, Taylor and Francis Group, Boca Raton, London, New York. 2009. I Website

3. Sastry R R, Rashmi H B and Rao N H. Nanotechnology for enhancing food security in India. Food Policy. 2011; 36:391-400. | Article

4. Alex W, Paul W, Lars F, Kiril H and Von Goetz N. Titanium di oxide in food and personal Care products. Environ Sci Technol. 2012; 6:2242-2250. | Article

5. Sanguansri $P$ and Augustine $M$ A. Nanoscale materials development: food industry perspective. Trends Food Sci Technol. 2006; 17:547-556. I Article

6. Jennifer M and Wnuk M. Nanoparticles technology as a double edged sword: cytotoxic: Genotoxic and epigenetic effects on living cells. Nanobiotech. 2013; 4:53-63. I Article

7. Ravichandran R. Nanotechnology application in food and food processing: innovative green approaches, opportunities and uncertainties for global market. Int J Green Nanotechnology, Physics and Chemistry. 2010; 1:P72-P96. | Article

8. Timothy V D. Application of nanotechnology in food packaging and food supply: Barrier materials, antimicrobial and sensors. J Colloid Interface Sci. 2011.

9. Emamifar A, Kadivar M, Shahedi M and Zad S S. Evaluation of nanocomposite packaging containing $\mathrm{Ag}$ and $\mathrm{ZnO}$ NPs on shelf-life of fresh orange juice. Innovative Food Sci and Emerging Technol. 2010; 11:742-748. | Pdf

10. Chaudhry $Q$ and Castel L. Food application of nanotechnologies: an overview of Opportunities and challenges for developing countries. Trends Food Sci Technol. 2011; 22:595-603. | Article

11. Huang $X$, Li Y, Chen $Y$, Zhou H, Duan X and Huang Y. Plasmonic and catalytic AuPd nanowheels for the efficient conversion of light into chemical energy. Angew Chem Int Ed Engl. 2013; 52:6063-7. | Article | PubMed

12. Sharon M, Sharon M, Pandey S and Oza G. Biotechnology concept and application. Ane Books (P) Ltd, New Delhi, Mumbai. 2012. I Pdf

13. Rather JA, Pilehvar S and De Wael K. A biosensor fabricated by incorporation of a redox mediator into a carbon nanotube/nafion composite for tyrosinase immobilization: detection of matairesinol, an endocrine disruptor. Analyst. 2013; 138:204-10. | Article | PubMed

14. RIKILT and JRC. Inventory of nanotechnology application in agriculture, feed and food Sector. FSA supporting publication. 2014; 125. | Article

15. Sahu J K. Introduction to advances food process engineering. CRS Press, Taylor and Francis Group, Boca Raton, FI, USA. 2014.

16. Chen H, Seiber JN and Hotze M. ACS Select on nanotechnology in food and agriculture: a perspective on implications and applications. J Agric Food Chem. 2014; 62:1209-12. | Article | PubMed

17. Malik A, Erginkaya Z, Ahmed S and Erten H. Food processing: strategies for quality assessment. Springer, New York, London. 2012. | Article

18. Sparrenberger K, Friedrich RR, Schiffner MD, Schuch I and Wagner MB. Ultra-processed food consumption in children from a Basic Health Unit. J Pediatr (Rio J). 2015. | Article | PubMed

19. Berekaa M M. Nanotechnology in food industry: advances in food processing, packaging and food safety. Int J Curr Microbiol App/ Sci. 2015; 4:345-357. I Pdf

20. El-Mashad $\mathrm{H}$ M and Pan Z. Food decontamination using nanomaterials. MOJ Food Processing and Technology. 2015; 2:00011. I Pdf
21. Simon $P$, Chaudhry $Q$ and Bakos D. Migration of engineered nanoparticles from polymer packaging of food-physicochemical review. J Food Nutri Res. 2008; 47:105-113.

22. Li $X$, Xing $Y$, Jiang $Y$, Ding $Y$ and Li W. Antimicrobial activities of ZnO powder coated PVC film to inactivate food pathogens. Int J Food Sci Technol. 2009; 44:2164-2168. | Article

23. John D F. New and emerging applications of nanotechnology in food supply. 2010. | Website

24. Tanja I R, Banka M P, Ivan S R, Oskar J B, Sebastian B and Novakovic A R. The influence of silica NPs on mechanical properties of polylactic acid as a food packaging material. Food and Feed Research. 2012; 39:97-102.

25. Huang X, Li Y, Chen Y, Zhou H, Duan X and Huang Y. Plasmonic and catalytic AuPd nanowheels for the efficient conversion of light into chemical energy. Angew Chem Int Ed Engl. 2013; 52:6063-7. | Article | PubMed

26. Lahir Y K. Toxicology. Agrobios (India), Jodhpur, India. 2009; 55-94.

27. Lahir Y K. Principles and applications of Toxicology. See Kay Publications, Bangalore, India. 2013; 45:171-172.

28. Chitra K and Annadurai G. Antimicrobial activity of wet chemically engineered spherical shaped ZnO NPs on food born pathogen. Int Food Res J. 2013; 20:59-64. | Pdf

29. Kamatou GP, Vermaak I and Viljoen AM. Eugenol--from the remote Maluku Islands to the international market place: a review of a remarkable and versatile molecule. Molecules. 2012; 17:6953-81. | Article I PubMed

30. Othman $\mathrm{S} \mathrm{H}$. Bionano-composite materials for food packaging applications. Agri Sci Proceedings. 2014; 2:296-303. | Article

31. Wang $H$, Wang J, Deng X, Sun H, Shi Z, Gu Z, Liu Y and Zhao Y. Biodistribution of carbon single-wall carbon nanotubes in mice. J Nanosci Nanotechnol. 2004; 4:1019-24. I PubMed

32. Smart S, Cassidy A T, Lu G Q, and Martin D J. Biocompatibility of CNTs. Carbon. 2006; 44:1034-1047. | Article

33. Fischer HC and Chan WC. Nanotoxicity: the growing need for in vivo study. Curr Opin Biotechnol. 2007; 18:565-71. | Article | PubMed

34. Curtis J, Greenberg M, Kester J, Phillips S and Krieger G. Nanotechnology and nanotoxicology: a primer for clinicians. Toxicol Rev. 2006; 25:24560. | PubMed

35. Hagens WI, Oomen AG, de Jong WH, Cassee FR and Sips AJ. What do we (need to) know about the kinetic properties of nanoparticles in the body? Regul Toxicol Pharmacol. 2007; 49:217-29. | Article I PubMed

36. Galvan-Garcia P, Keefer EW, Yang F, Zhang M, Fang S, Zakhidov AA, Baughman RH and Romero MI. Robust cell migration and neuronal growth on pristine carbon nanotube sheets and yarns. J Biomater Sci Polym Ed. 2007; 18:1245-61. | Article | PubMed

37. Jan E and Kotov NA. Successful differentiation of mouse neural stem cells on layer-by-layer assembled single-walled carbon nanotube composite. Nano Lett. 2007; 7:1123-8. | Article | PubMed

38. Oberdorster G, Maynard A, Donaldson K, Castranova V, Fitzpatrick J, Ausman K, Carter J, Karn B, Kreyling W, Lai D, Olin S, Monteiro-Riviere N, Warheit $D$ and Yang $H$. Principles for characterizing the potential human health effects from exposure to nanomaterials: elements of a screening strategy. Part Fibre Toxicol. 2005; 2:8. | Article | PubMed Abstract | PubMed Full Text

39. Forbe T, Garcia M, and Gonzalez E. Potential risk of NPs. Cienc Technol Aliment. 2011; 31. I Pdf

40. Clift MJ, Varet J, Hankin SM, Brownlee B, Davidson AM, Brandenberger C, Rothen-Rutishauser B, Brown DM and Stone V. Quantum dot cytotoxicity in vitro: an investigation into the cytotoxic effects of a series of different surface chemistries and their core/shell materials. Nanotoxicology. 2011; 5:664-74. | Article | PubMed

41. Pardeshi P, Nawale A B, Mathe V L, Lahir Y K and Dongre P M. Effects of zinc oxide nanoparticleson the hepatic tissue of chicken embryo: $A$ histological approach. Bionano Frontier. 2014; 2:176-180. | Pdf

42. Shirsekar P P, Kanhe N, Mathe V L, Lahir Y K and Dongre P M. Interaction of zinc oxide Nanoparticles with human red blood cells. Bionano 


\section{frontier. 2015. | Website}

43. Baek M, Chung HE, Yu J, Lee JA, Kim TH, Oh JM, Lee WJ, Paek SM, Lee JK, Jeong J, Choy JH and Choi SJ. Pharmacokinetics, tissue distribution, and excretion of zinc oxide nanoparticles. Int I Nanomedicine. 2012; 7:308197. | Article | PubMed Abstract | PubMed Full Text

44. Cho W-S, Kang B-C, Lee J K, Jeong J, Che J-H and Seok S-H. Comparative adsorption, distribution and excretion of $\mathrm{TiO}_{2}$ and $\mathrm{ZnO} \mathrm{NPs}$ after oral administration. Particle Fiber Toxicology. 2013; 10:9.

45. Zhao B, Sun L, Zhang W, Wang Y, Zhu J, Zhu X, Yang L, Li C, Zhang Z and Zhang Y. Secretion of intestinal goblet cells: a novel excretion pathway of nanoparticles. Nanomedicine. 2014; 10:839-49. | Article | PubMed

46. Huang X C, Luo Y L and Hsu H S. Redox-triggered biocompatible inorganic nanoplate Form for cancer theranostics, In; Biological and Pharmaceutical applications of nanomaterials. Ed. Prokopovich, CRS Press, Taylor Francis group, Boca. 2015.

47. Coccini T, Manzo $L$ and Roda E. Safety evaluation of engineered nanomaterials for health risk assessment: an experimental tiered testing approach using pristine and functionalized carbon nanotubes. ISRN Toxicol. 2013; 2013:825427. | Article | PubMed Abstract | PubMed Full Text

48. Wu W, Ichihara G, Suzuki Y, Izuoka K, Oikawa-Tada S, Chang J, Sakai K, Miyazawa K, Porter D, Castranova V, Kawaguchi M and Ichihara S. Dispersion method for safety research on manufactured nanomaterials. Ind Health. 2014; 52:54-65. | Article | PubMed Abstract | PubMed Full Text

49. Szakal C, Roberts SM, Westerhoff P, Bartholomaeus A, Buck N, Illuminato I, Canady R and Rogers M. Measurement of nanomaterials in foods: integrative consideration of challenges and future prospects. ACS Nano. 2014; 8:3128-35. | Article | PubMed

50. Hou X, Zhang J, Ahmad H, Zhang H, Xu Z and Wang T. Evaluation of antioxidant activities of ampelopsin and its protective effect in lipopolysaccharide-induced oxidative stress piglets. PLoS One. 2014; 9:e108314. | Article | PubMed Abstract | PubMed Full Text

51. Vert $M$, Doi $Y$, Hellwich $K H$, Hess $M$, Hedge $P$, Kubisa $P$, Renado $M$ and Schue F. Terminology for biorelated polymers and applications, (IUPAC Recommendations. Pure App Chem. 2012; 84:377-410. | Article

52. CDC- Medicine.

53. Williams D F. On the mechanism of biocompatibility. Biomaterials. 2008; 29:2941-2953. | Article

54. He L, Liu Y, Mustapha A and Lin M. Antifungal activity of zinc oxide nanoparticles against Botrytis cinerea and Penicillium expansum. Microbiol Res. 2011; 166:207-15. | Article | PubMed

55. Chuah AM, Kuroiwa T, Ichikawa S, Kobayashi I and Nakajima M. Formation of biocompatible nanoparticles via the self-assembly of chitosan and modified lecithin. J Food Sci. 2009; 74:N1-8. | Article | PubMed

56. Gurunathan S, Han J, Park J H and Kim J H. A green chemistry approach for synthesizing biocompatible gold NPs. Nanoscale Res Letters. 2014; 9:246. | Article

57. Wang F, Gao F, Lan M, Yuan H, Huang Y and Liu J. Oxidative stress contributes to silica nanoparticle-induced cytotoxicity in human embryonic kidney cells. Toxicol In Vitro. 2009; 23:808-15. | Article | PubMed

58. Christen V and Fent K. Silica nanoparticles and silver-doped silica NPs induce Endoplasmic reticulum stress response and alter cytochrome P450 1A activity. Chemosphere. 2012; 87:423-434 | Article

59. DeVoll J R. Nanoparticles toxicity. Aviat Space Environ Med. 2010; 81:152-163. | Article | PubMed

60. Raghunathan V K, Hawkins S, Case C P, Mann S, Davis S and Lane J. Factors that may Affect the nanotoxicity of heard materials for surgica application, Characterizing potential, risk posed by engineered NPs. A second U K Govt. research report Programme project. 2011.

61. Elsaesser A and Howard CV. Toxicology of nanoparticles. Adv Drug Deliv Rev. 2012; 64:129-37. | Article | PubMed

62. Cortajareno A L. Otega D, Ocampo S M, Gonzalez-Gracia A, Couleaud P. Cristobal B-I and Angel A-S. Engineering iron oxide nanoparticles for clinical settings. Nanomedicine. 2014; $1: 2$. I Pdf

63. Seabra AB, Paula AJ, de Lima R, Alves OL and Duran N. Nanotoxicity of graphene and graphene oxide. Chem Res Toxicol. 2014; 27:159-68. | Article I PubMed

64. GonzaloR-G, Zimmermann B and Weil M W. Nanotoxicity and life cycle assessment. $1^{\text {st }}$ attempt towards the determination of characterization factors for carbon nanotubes, $2^{\text {nd }}$ Int Conference on structural nanocomposite (NANOSTRUCTURES 2014), IOP Publishing, IOP Conf. Series, Materials Sci and Engineering. 2014; 64:012029.

65. Austruc $D$ and Chardac F. Dendritic catalytic and dendrimers in catalysis. Chem Rev. 2001; 101:2991-3024. | Pdf

66. Bardi G, Tognini P, Ciofani G, Raffa V, Costa M and Pizzorusso T. Pluroniccoated carbon nanotubes do not induce degeneration of cortical neurons in vivo and in vitro. Nanomedicine. 2009; 5:96-104. | Article | PubMed

67. Sahu S C and Casciano D A. Hand book of nanotoxicology, Nanomedicine and stem cell use in Toxicology. John Wiley and sons. 2014. I Article

68. Zeng $Q$, Shao D, Ji W, Li J, Li C and Song J. The nanotoxicity investigation of optical nanoparticles to cultured cells in vitro. Toxicology Reports. 2014; 1:137-144. | Article

69. Watson C, Ge J, Cohen J, Pyrgiotakis G, Engelward BP and Demokritou $P$. High-throughput screening platform for engineered nanoparticlemediated genotoxicity using CometChip technology. ACS Nano. 2014; 8:2118-33. | Article | PubMed Abstract | PubMed Full Text

70. Kumar V, Kumari A, Guleria P and Yadav SK. Evaluating the toxicity of selected types of nanochemicals. Rev Environ Contam Toxicol. 2012; 215:39-121. | Article | PubMed

71. Xu X, Wang X, Li Y, Wang Y and Yang L. A large-scale association study for nanoparticle $\mathrm{C} 60$ uncovers mechanisms of nanotoxicity disrupting the native conformations of DNA/RNA. Nucleic Acids Res. 2012; 40:7622-32. | Article | PubMed Abstract | PubMed Full Text

72. Jia $H$, Zhu $G$ and Wang P. Catalytic behaviors of enzymes attached to nanoparticles: the effect of particle mobility. Biotechnol Bioeng. 2003; 84:406-14. | Article | PubMed

73. Badadi V Y, Najafi L, Najafi A, Gholami H, Zarji M E B, Golzadeh J, Amraie $E$ and Ali S. Evaluation of iron oxide NPs effects on tissue and enzymes of liver in rats. J Pharmac Biomed Sci. 2012; 23:1-4. I Pdf

74. Nagy H E. Comparison of the structure and stability of single enzyme NPs. Hungarian J Indust Chemist Veszprem. 2009; 37:123-130.

75. Negahdary $M$ and Ajdary M. The toxicity of gold, silver and ZnO NPs on enzyme LDH in male mice. Annual Res and Review in Biology. 2014; 4:1346-1352. | Article

76. Ong KJ, MacCormack TJ, Clark RJ, Ede JD, Ortega VA, Felix LC, Dang MK, Ma G, Fenniri H, Veinot JG and Goss GG. Widespread nanoparticle-assay interference: implications for nanotoxicity testing. PLoS One. 2014; 9:e90650. | Article | PubMed Abstract | PubMed Full Text

77. Lahir Y K. Lipid oxidation in biological systems: Biochemical, Biological and Biophysical aspects. Global J B B. 2015; 4:224-233.

78. Matuszak J, Zaloga J, Friedrich R P, Layer S, Nowak J, Odenbach S, Alexiou $\mathrm{C}$ and Cicha I. Endothelial biocompatibility and accumulation of SPION under flow conditions. J Magnetism Magnetic materials. 2015; 380:2026. | Article

79. Soenen S J, Parak W J, Rejman J and Manshian B. Intracellular stability of inorganic NPs; effects on cytotoxicity, particle functionality and biomedical applications. Chemical Rev. 2015; 115:2109-21135. | Article

80. Shvedova AA, Castranova V, Kisin ER, Schwegler-Berry D, Murray AR, Gandelsman VZ, Maynard A and Baron P. Exposure to carbon nanotube material: assessment of nanotube cytotoxicity using human keratinocyte cells. J Toxicol Environ Health A. 2003; 66:1909-26. | Article I PubMed

81. Cui D, Tian F, Ozkan CS, Wang M and Gao H. Effect of single wall carbon nanotubes on human HEK293 cells. Toxicol Lett. 2005; 155:73-85. | Article I PubMed

82. Jia G, Wang H, Lei Y, Pei R, Yan T, Zhao Y and Guo X. Cytotoxicity of carbon nanomaterials:single walled nanotubes, multi walled nanotubes. Environ Sci Technol. 2005; 39:1378-1383. | Article 
Lahir Yogendra Kumar, Journal of Toxicology and Health 2015, http://www.hoajonline.com/journals/pdf/2056-3779-2-2.pdf

83. Davoren M, Herzog E, Casey A, Cottineau B, Chambers G, Byrne HJ and Lyng FM. In vitro toxicity evaluation of single walled carbon nanotubes on human A549 lung cells. Toxicol In Vitro. 2007; 21:438-48. | Article | PubMed

84. Lin W, Isaac S, Huang Y, Znou X and Yinfa Ma. Cytotoxicity and cell membrane depolarization induced by aluminium oxide NPs in human lung epithelial cells A549. Toxicol Environ Chem. 2008; 90:983-996. | Article

85. Verma A, Uzun O, Hu Y, Han HS, Watson N, Chen S, Irvine DJ and Stellacci F. Surface-structure-regulated cell-membrane penetration by monolayer-protected nanoparticles. Nat Mater. 2008; 7:588-95. | Article | PubMed Abstract | PubMed Full Text

86. Wang F, Gao F, Lan M, Yuan H, Huang $Y$ and Liu J. Oxidative stress contributes to silica nanoparticle-induced cytotoxicity in human embryonic kidney cells. Toxicol In Vitro. 2009; 23:808-15. | Article | PubMed

87. Li X, Xing Y, Jiang Y, Ding Y and Li W. Antimicrobial activities of ZnO powder coated PVC film to inactivate food pathogens. Int J Food Sci Technol. 2009; 44:2164-2168. | Article

88. Bardi G, Nunes A, Gherardini L, Bates K, Al-Jamal KT, Gaillard C, Prato M, Bianco A, Pizzorusso $T$ and Kostarelos K. Functionalized carbon nanotubes in the brain: cellular internalization and neuroinflammatory responses. PLoS One. 2013; 8:e80964. | Article | PubMed Abstract | PubMed Full Text

89. Olson J L, Raul V M, Nicole N, David A A, Mandava N and Stodlt C R. Intraocular biocompatibility of AuNPs. J Nanomater Mol Nanotechnol. 2013; 2:2. I Article

90. Ingrid L B and Frank A W. NPs toxicity by gastrointestinal route: evidence and Knowledge gaps. Int J Biomed Nanosci Nanotechnol. 2013; 3:1-2. I Article

91. Lam CW, James JT, McCluskey R, Arepalli S and Hunter RL. A review of carbon nanotube toxicity and assessment of potential occupational and environmental health risks. Crit Rev Toxicol. 2006; 36:189-217. | Article I PubMed

92. Benedicte T, Ramune R, Haywest B, Parrisa S and Schiestl R H. Titaniumdi-oxide nanoparticles induce DNA damage and genetic instability in vivo in mice. Cancer Res.2009; 69:8784. I Article

93. Wu Z, Bin Z and Yan B. Regulation of enzyme activity through interaction with NPs. Int J Mol Sci. 2009; 10:4198-4209. | Article

94. Badadi V Y, Najafi L, Najafi A, Gholami H, Zarji M E B, Golzadeh J, Amraie $E$ and Ali S. Evaluation of iron oxide NPs effects on tissue and enzymes of liver in rats. J Pharmac Biomed Sci. 2012; 23:1-4. I Pdf

95. Gaharwar U S and Paulraj R. Iron oxide NPs induced oxidative damage in peripheral Blood cells. J Biomedical Sci and Engineering. 2015; 8:274286. | Article

\section{Citation:}

Kumar LY. Role and adverse effects of nanomaterials in food technology. J Toxicol Health. 2015; 2:2.

http://dx.doi.org/10.7243/2056-3779-2-2 